\title{
Stability studies of endocrine disrupting tributyltin and triphenyltin compounds in an artificial sea water model
}

\author{
Ladislav Novotny ${ }^{1}$, Leyla Sharaf ${ }^{1}$, Mohammed E. Abdel-Hamid ${ }^{1}$ and Julius Brtko ${ }^{2}$ \\ ${ }^{1}$ Department of Pharmaceutical Chemistry, Faculty of Pharmacy, Kuwait University, Kuwait City, Kuwait \\ ${ }^{2}$ Institute of Experimental Endocrinology, BMC, Slovak Academy of Sciences, Bratislava, Slovakia
}

\begin{abstract}
Triorganotins belong to toxic components present predominantly in antifouling paints for marine vessels. Tributyltin/triphenyltin at pico- or nanomolar concentrations in sea water are known to induce an irreversible sexual abnormality in females of over 190 marine species, an "imposex" phenomenon - the superimposition of male genitalia on a female. Moreover, trialkyltins and triaryltins function as potent nuclear retinoid X receptors (RXR) agonists. In mammals, triorganotin compounds induce immunosuppressive, metabolic, reproductive or developmental effects. Toxic effects of triorganotins warrant the need for monitoring of their long-lasting presence in the environment. This study brings novel data on the stability of two triorganotin compounds in artificial sea water model obtained by applying ultra-pressure liquid chromatography (UPLC) and gas chromatography-mass spectrometry (GC-MS) methods. Stability of tributyltin and triphenyltin chlorides was studied for 180 days and the degradation kinetic parameters were obtained. Tributyltin chloride was the less stable with the degradation kinetic parameters $\mathrm{K}_{\mathrm{deg}}=0.00014$ day $^{-1}$ and $t_{1 / 2}=4950$ days (13.6 years). $K_{\text {deg }}$ of the more stable triphenyltin chloride was determined to be $\mathrm{K}_{\mathrm{deg}}=0.00006$ day $^{-1}$ with $\mathrm{t}_{1 / 2}=11550$ days ( 31.6 years). Since similar stability data of triorganotin compounds were not published previously, we report high stability for both tested compounds, which indicates a significant environmental problem when these substances enter sea water and later coastal sediments.
\end{abstract}

Key words: Triorganotins - Sea water stability - UPLC - GC-MS

\begin{abstract}
Abbreviations: ER, estrogen receptor; FXR, farnesoid X receptor; GC, gas chromatography; LXR, liver X receptor; MS, mass spectrometry; PPAR, peroxisome proliferator-activated receptor; PXR, pregnane X receptor; RAR, all-trans retinoic acid receptor; RXR, retinoid X receptor; TR, thyroid hormone receptor; UPLC, ultra-pressure liquid chromatography; VDR, dihydroxyvitamin $\mathrm{D}_{3}$ receptor.
\end{abstract}

\section{Introduction}

Triorganotin compounds are known as components of antifouling paints for marine vessels. They are also components of heat stabilizers in vinyl chloride polymers (PVC), wood preservatives, agricultural pesticides, disinfecting agents in industrial cooling waters and industrial catalysts in a variety

Correspondence to: Ladislav Novotny, Department of Pharmaceutical Chemistry, Faculty of Pharmacy, Kuwait University, Kuwait City, Kuwait

E-mail: novotny@hsc.edu.kw of chemical reactions (Kotake 2012). In general, organotin compounds are components of a variety of plastics, including silicone. Their occurrence is almost everywhere, e.g. in food containers, medical devices, toys, wallpaper, household piping, etc. (Sousa et al. 2014). Due to organotin compounds widespread use, organotins can be detected in soils and sediments, water and also in the atmosphere (Kannan et al. 2010). Triorganotin compounds, predominantly of tributyltin (TBT) origin have been largely released into water from antifouling paints, resulting in bizarre effects on aquatic organisms (Sousa et al. 2014). TBT at pico- or nanomolar concentrations was found to induce an irrevers- 
A

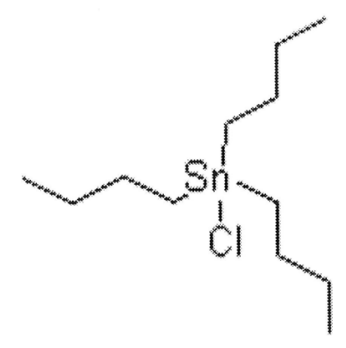

B

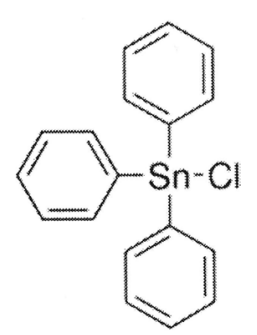

Figure 1. Chemical formulas of tributyltin chloride (A) and triphenyltin chloride (B).

ible sexual abnormality in female molluscs, a phenomenon known as "imposex" (the superimposition of male genitalia on female). In the other words, TBT can cause irreversible sex-organ alterations as a result of masculinization process by which a penis and a vas deferens develop in more than 190 marine species (Nakanishi 2008). Trialkyltins, e.g. tributyltin, and triaryltins, e.g. triphenyltin (Fig. 1), function as potent nuclear retinoid X receptors (RXR) agonists due to their capability to bind to the ligand-binding domain of RXR subtypes and function as transcriptional activators (Nakanishi et al. 2005, Brtko and Dvorak 2015). This phenomenon was very recently confirmed also by radioligand binding assay (Toporova et al. 2016). The effect of selected triorganotins on nuclear retinoid and retinoid $\mathrm{X}$ receptor subtypes expression in human breast cancer cells clearly confirmed their potency to affect nuclear receptors at the mRNA or protein level (Macejova et al. 2017). Since RXRs can act predominantly as heterodimeric partners of a number of other nuclear receptors, including retinoic acid receptors (RARs), thyroid hormone receptors (TRs), dihydroxyvitamin $\mathrm{D}_{3}$ receptor (VDR), peroxisome proliferator-activated receptors (PPARs), liver X receptors (LXRs), farnesoid X receptor (FXR), pregnane $\mathrm{X}$ receptor (PXR), constitutive androstane receptor (CAR), and several orphan receptors, then RXR subtypes play a crucial role in the modulation of many hormonal signals and regulatory pathways within the cells (Brtko and Dvorak 2011, 2015; Flodrova et al. 2016; Macejova et al. 2016). In mammals, organotin compounds also induce immunosuppressive, metabolic, reproductive or developmental effects (leMaire et al. 2009, Macejova et al. 2016).

All the interesting biological activities and toxic effect of triorganotin substances draw the attention to monitoring and regulation of their presence in the environment. Consequently, the development of modern sensitive and selective instrumental analytical techniques for the extraction, pre-concentration and determination these substances followed (Cole et al. 2015). This resulted in some data available on the presence of organotin substances in the

environment (Arp et al. 2014; Rodriguez-Cea et al. 2015; Suzdalev et al. 2015). However, no data are available on the rate of degradation of individual triorganotin substances in the sea environment.

The aim of this study was to bring novel data on the stability of tributyltin and triphenyltin chlorides in artificial sea water, which was achieved by using the ultra-pressure liquid chromatography (UPLC) and gas chromatography-mass spectrometry (GC-MS) methods.

\section{Material and Methods}

\section{Preparation of solutions}

On average, sea water in the world's oceans has a salinity of about $3.5 \%(35 \mathrm{~g} / \mathrm{l})$ of predominantly sodium and chloride ions. Stock solutions were prepared by dissolving $20 \mathrm{mg}$ of each compound (tributyltin chloride or triphenyltin chloride) in $5 \mathrm{ml}$ of 50:50 artificial sea water: methanol solution. Both triorganotin compounds were purchased from SigmaAldrich (Germany) with purity $96 \%$ and $95 \%$, respectively, as declared by the chemical distributor. The solutions were sonicated for $30 \mathrm{~min}$ to ensure complete dissolution of the compounds. Working solutions were prepared by diluting $200 \mu \mathrm{l}$ of stock solution in $1 \mathrm{ml}$ of mobile phase $(80: 20 \mathrm{v} / \mathrm{v}$ acetonitrile: $\mathrm{H}_{2} \mathrm{O}$ ).

\section{UPLC instrumental conditions}

High purity water was obtained using Milli-Q water purification system. HPL grade methanol and acetonitrile were used. The mobile phase was filtered through a $0.2 \mu$ m nylon membrane filter from Millipore and degassed daily before use. Separation was achieved using a mobile phase that consists of 80:20 (acetonitrile: $\mathrm{H}_{2} \mathrm{O}$ ) at a flow rate of $0.4 \mathrm{ml} /$ min in only 4 -min runtime. The column temperature was maintained at $40^{\circ} \mathrm{C}$, injection volume was $10 \mu \mathrm{l}$ and detection wavelength was set at $254 \mathrm{~nm}$ for determination of triorganotin chlorides.

The fast liquid chromatography was performed using UPLC system (Waters' Equipment Company, Inc., U.S.A.) with Acquity TUV detector. Chromatogram and data were recorded by means of Empower software. The chromatographic system was performed using Acquity BEH C18 $(100 \times 2.1 \mathrm{~mm}) \mathrm{id}, 1.7 \mu \mathrm{m}$ column.

\section{Stability study}

All solutions used in the study were prepared at an initial concentration of $4 \mathrm{mg} / \mathrm{ml}$ and put in an incubator (GFL, U.S.A) at $60^{\circ} \mathrm{C}$ for 1,2 , and 3 hours. All solutions were then diluted in the mobile phase to give a final concentration of 
$0.8 \mathrm{mg} / \mathrm{ml}$ and filtered before injection. Readings were taken at zero time, after 1, 2 and 3-hours incubation at $60^{\circ} \mathrm{C}$. Readings also were taken after 3 days, 7 days and after 6 months of keeping solutions at room temperature.

\section{GC-MS instrumental conditions}

The GC-MS chromatography experiments were performed using Trace GC Ultra-ISQ (Manufacturer: Thermo Scientific, USA). All operating and data acquisition were processed by Excalibur software. Library search was done using the library NIST MS Search 2.0 of equipment. GC separation of analytes was achieved by TG-SQC GC column: $15 \mathrm{~m} \times$ $0.25 \mathrm{~mm} \times 0.25 \mu \mathrm{m}$ (Thermo Scientific) using the following temperature program: Initial temperature of the experiment was $50^{\circ} \mathrm{C}$ with the hold time of $1 \mathrm{~min}$ and then $280^{\circ} \mathrm{C}$ with the hold time of $10 \mathrm{~min}$ at the rate $30^{\circ} \mathrm{C} / \mathrm{min}$. Total run time was 19 minutes.

Solutions of tributyltin chloride, triphenyltin chloride and tetraphenyltin chloride were prepared in methanol at concentrations $100 \mu \mathrm{l} / \mathrm{ml}$ and $100 \mu \mathrm{g} / \mathrm{ml}$, respectively (according to the sample). An aliquot of 1-2 $\mu$ l of each solution was injected into GC. The MS profiles were matched with NIST library of the instrument for detection.

The conditions used for MS analysis by ISQ Mass Spectrometer were: MS transfer line temperature of $250^{\circ} \mathrm{C}$, ion source temperature of $200^{\circ} \mathrm{C}$, EI (electrospray ionization) mode and mass detection ( $\mathrm{m} / \mathrm{z}$; mass/charge number of the ions) in the range of 50-450. Helium gas Grade 6 (99.9999\%) at a flow rate of $1.2 \mathrm{ml} / \mathrm{min}$ was used.

\section{Procedure}

Solutions of tributyltin and triphenyltin chlorides were prepared in methanol at concentrations $100 \mu \mathrm{l} / \mathrm{ml}$ and $100 \mu \mathrm{g} /$ ml, respectively. An aliquot of $1-2 \mu l$ of each solution was injected into GC. The MS profiles were matched with NIST library of the instrument for detection.

\section{Kinetics calculation for organotins degradation}

Based on the UPLC determination of stability after 6 storage of the solutions at the room temperature, the degradation kinetic parameters, $\mathrm{K}_{\mathrm{deg}}$ and $\mathrm{t}_{1 / 2}$, in artificial sea water were calculated (Carstensen 1995).

\section{Results}

GC-MS

The GC-MS analysis of the first compound - tributyltin chloride (TBT) showed GC peak at retention time (Rt) 6.04 min (Fig. 2A) with ion masses at $\mathrm{m} / \mathrm{z} 292,269,213,155$ and 119 (Fig. 2B). These ions originated from the fragmentation of the parent compound - tributyltin chloride. The molecular peak of the parent molecule was not detected due to the low stability of the molecule under MS conditions. This is in an agreement with the data from the Excalibur library where the tributyltin chloride spectrum also does not contain the molecular peak of MW 326. As stated by the producer (Sigma-Aldrich, U.S.A.), GC showed the presence of some impurities of these compounds. This is in good agreement with the declared purity of used compounds, which declared purity of tributyltin chloride and triphenyltin chloride equal to $96 \%$. The identification of these impurities was not performed.

On the other hand, the GC-MS profile of the second compound triphenyltin chloride (TPT), indicated the presence of 2 GC peaks at the retention times Rt $8.76 \mathrm{~min}$

\section{A}

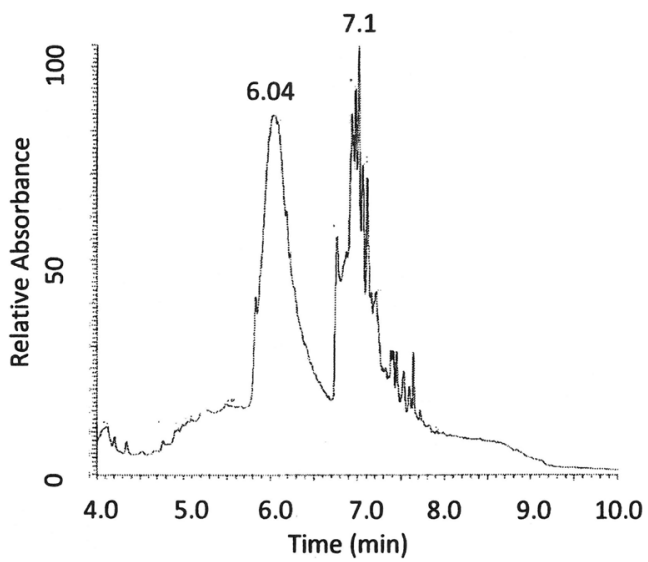

B

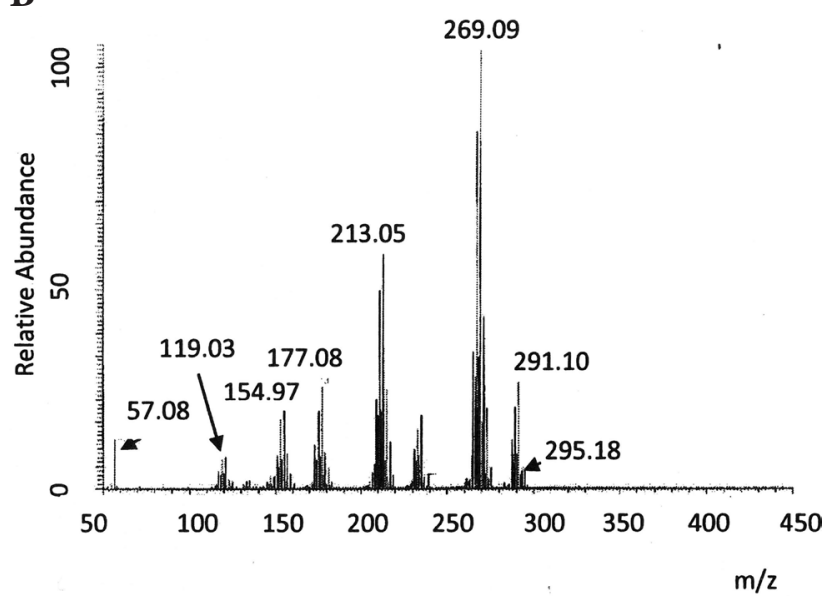

Figure 2. GC chromatogram (A) and MS spectrum (B) of commercial tributyltin chloride. A: Peak RT (retention time) $6.04 \mathrm{~min}$, tributyltin chloride; RT 7.01 min, impurities. 
A

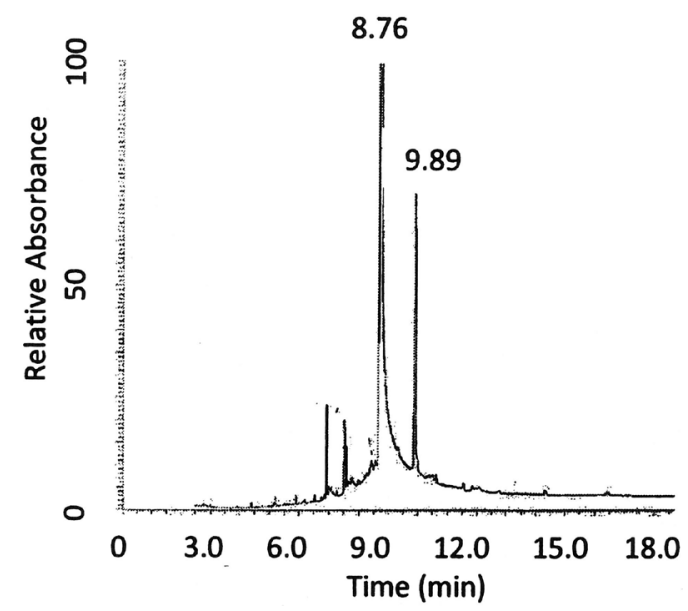

B

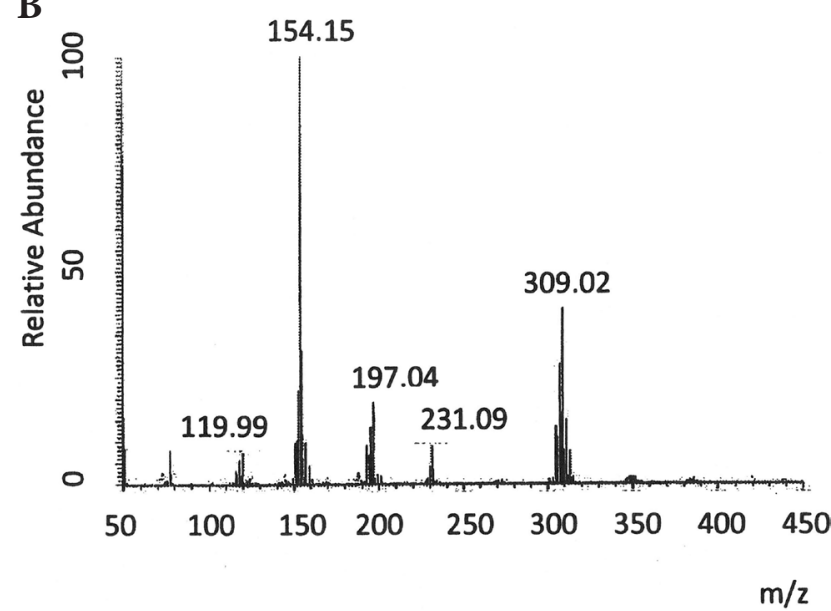

C

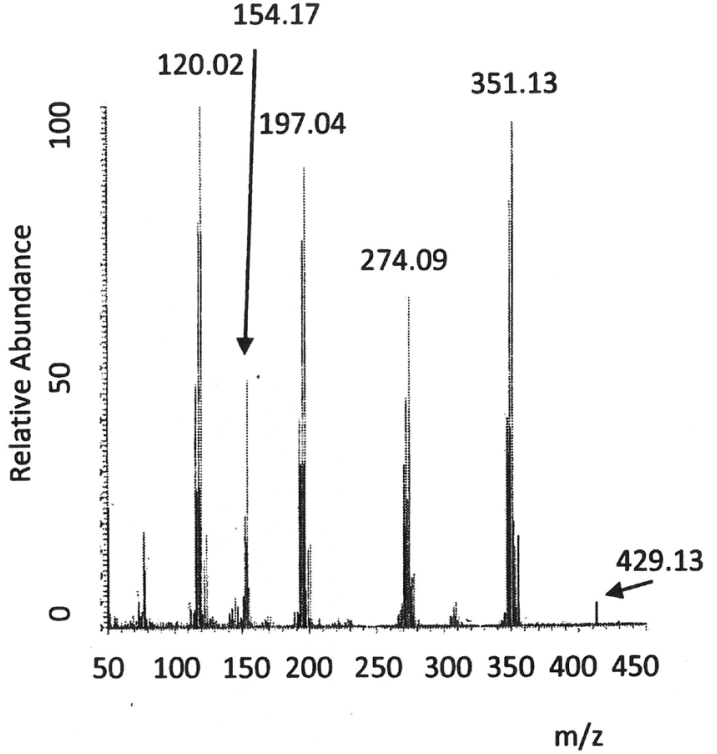

Figure 3. GC chromatogram of commercial triphenyltin chloride (A) and MS spectrum of triphenyltin chloride (B) and of impurity - tetraphenyltin (C). RT $8.76 \mathrm{~min}$, triphenyltin chloride; RT $9.89 \mathrm{~min}$, tetraphenyltin. and $9.89 \mathrm{~min}$ (Fig. 3A) that referred to chlorotriphenyltin chloride (m/z 386, 309, 231, 197, 154, 120) (Fig. 3B) and tetraphenyltin ( $\mathrm{m} / \mathrm{z} 428,351,197$ - this peak seems to be identical to the peak of 196 from the spectra of triphenyltin chloride) (Fig. 3C). The peak with m/z 120 - tin, also appears and is identical to the peak from the MS spectrum of triphenyltin chloride - see Fig. 3B). The presence of the impurities is also in an agreement with declared-by-theproducer purity of $96 \%$.

The MS data served as a base for designing the fragmentation process of both investigated substances (Figs. 4A and 4B) and one impurity (tetraphenyltin) (Fig. 4C).

\section{UPLC}

By referring to the chromatograms, each compound exhibited well-resolved peaks at retention times between $0.49 \mathrm{~min}$ (tributyltin chloride) (Fig. 5A) and 0.56 min (triphenyltin chloride) (Fig. 6A).

Significant stability of tributyltin chloride was observed after 60 and even after 180 days at laboratory temperature. One extra peak at retention time $=0.415 \mathrm{~min}$ increased in size indicating the degradation of tributyltin chloride (Fig. $5 B)$. The degradation of tributyltin chloride in a solution of artificial sea water kept at laboratory temperature for 6 months was approximately $13 \%$ of the original concentration of tributyltin chloride.

The area values of triphenyltin chloride showed excellent stability over a two and six month periods. No specific degradation peak was detected (compare Figs. 6A and 6B).

The degradation parameters (degradation constant $\mathrm{K}_{\mathrm{deg}}$ and half-life time $\mathrm{t}_{1 / 2}$ ) of both compounds were calculated using linear regression analysis. Tributyltin chloride was the less stable from both compounds with $\mathrm{K}_{\mathrm{deg}}=0.00014 / \mathrm{day}$ and $t_{1 / 2}=4950$ days (13.6 years). $K_{\text {deg }}$ of the more stable triphenyltin was determined to be $K_{\mathrm{deg}}=0.00006 /$ day with $\mathrm{t}_{1 / 2}=11550$ days (31.6 years).

\section{Discussion}

Triorganotin substances are very stable because of their chemical nature. Investigation of the rates of their degradation is very important as it may elucidate expectation on their degradation in sea water and also in sediments. Their synthesis is difficult and, consequently, their declared purity of commercial products is never close to $100 \%$. However, this does not represent a problem as their main use is as antifouling substances for ships and ports protection. In this work, we looked into the stability of two substances - tributyltin and triphenyltin chlorides (Fig. 1) as they represent two main groups of tin products, i.e. butyl substituted and phenyl substituted. Application 
A

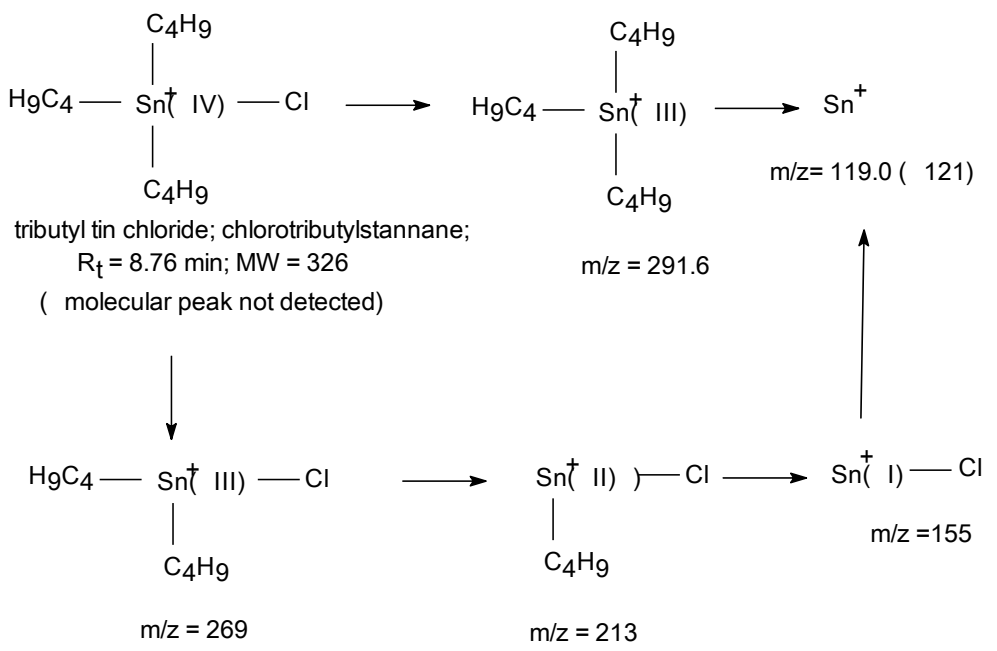

B

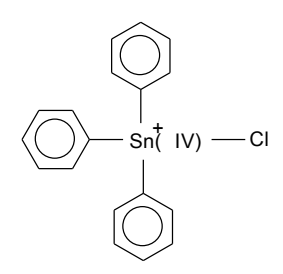

triphenyl tin chloride; chlorotriphenylstannane;

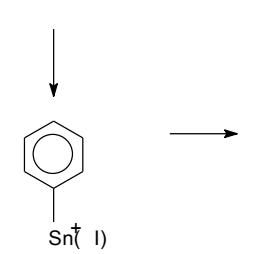

$\mathrm{m} / \mathrm{z}=196$
C

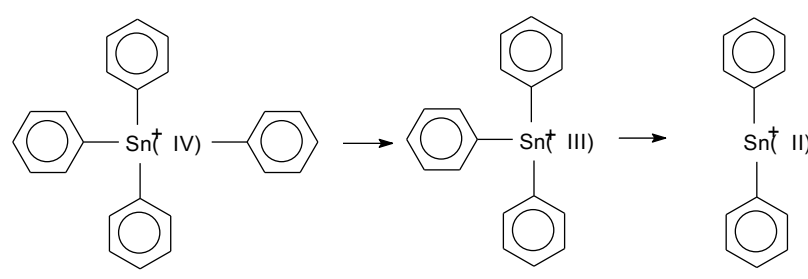

$\mathrm{m} / \mathrm{z}=351$

$\mathrm{m} / \mathrm{z}=231$

$\mathrm{m} / \mathrm{z}=309$

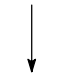

$\mathrm{Sn}^{+} \longleftarrow \mathrm{Sn}^{+}(\mathrm{I})-\mathrm{Cl}$

$\mathrm{m} / \mathrm{z}=120$

$\mathrm{m} / \mathrm{z}=154$ $\mathrm{m} / \mathrm{z}=274$

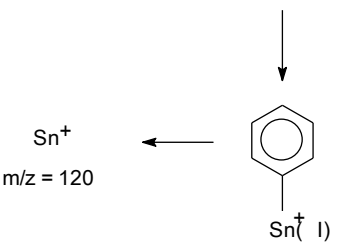

$\mathrm{m} / \mathrm{z}=197$

Figure 4. MS fragmentation of tributyltin chloride (A), triphenyltin chloride (B) and tetraphenyltin (C).

of modern instrumental analytical technique, UPLC, represents a novel use of this technique. This is important due to the fact that the presence of the substances investigated in the marine environment was established and consequently, their negative biological and toxic effects can take place. Additionally, the use of modern sensitive and selective instrumental technique for their study is very important as it makes monitoring of marine environment and determination more reliable, economical and suitable for routine determinations. As shown earlier, data on the availability of organotins in the environment are available (Arp et al. 2014; Rodriguez-Cea et al. 2015, Suzdalev et al. 2015). However, the importance of our study is based on non-availability of data on triorganotin degradation/stabil- ity of these substances. For the first time, this manuscript conveys information on the stability of two organotins in an artificial sea water that mimics conditions in sea and ocean environment

Our study is complemented by GC-MS spectra that confirmed the presence of approximately $4 \%$ of impurities in tested substances. The fragmentations of the triorganotin chlorides tested and also of tetraphenyltin was designed.

The high stability of both tested compounds with half-life times for tributyltin chloride being 13.6 years and for triphenyltin chloride 31.6 years indicates a significant environmental problem when these substances enter sea water and sediments. Based on the chemical structure, it is reasonable to 
A

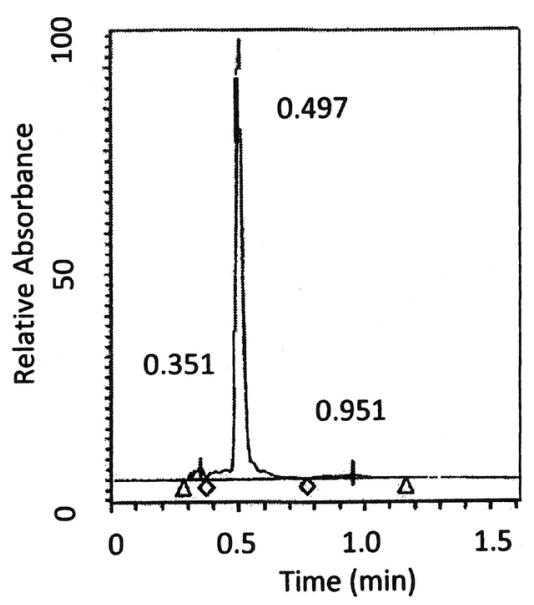

B

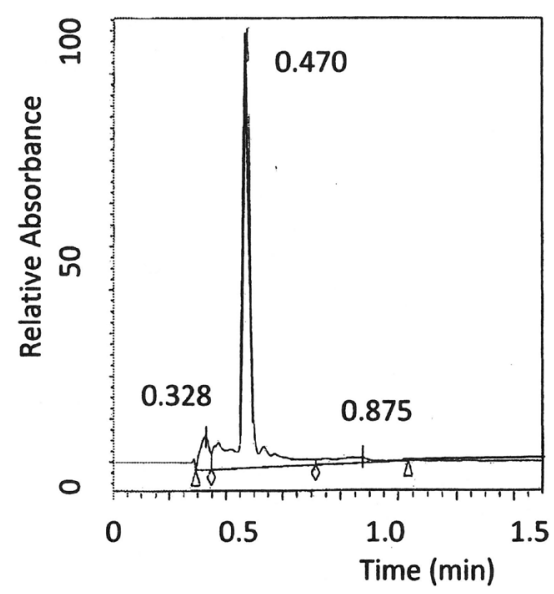

Figure 5. UPLC chromatogram of tributyltin chloride in solution at zero time (A) and after 180 days at room temperature (B). A: Peak RT (retention time) $0.351 \mathrm{~min}$, area $15041 \mathrm{RA}$; RT $0.497 \mathrm{~min}$, area 443735 RA; RT $0.951 \mathrm{~min}$, area 16563 RA. B: Peak RT $0.328 \mathrm{~min}$ area $33868 \mathrm{RA}$; RT $0.470 \mathrm{~min}$, area $427382 \mathrm{RA}$; RT $0.875 \mathrm{~min}$, area 30019 RA. (Area of peaks shown as "relative absorbance units", RA).

expect that the triphenyltin chloride impurity - tetraphenyltin - is even more stable. On the other hand, the contribution of other environmental factors, such as UV radiation or presence of various microorganisms, may probably contribute to the higher rate of degradation of triorganotins. However, tin will still remain as a toxic pollutant in the environment after any of organic tin substance degradation.

Acknowledgements. This work was supported by the Slovak Republic APVV-15-0372 and APVV-0160-11 grants and by Faculty of Pharmacy, Kuwait University.

Conflict of interest. The authors declare that there is no conflict of interest.
A

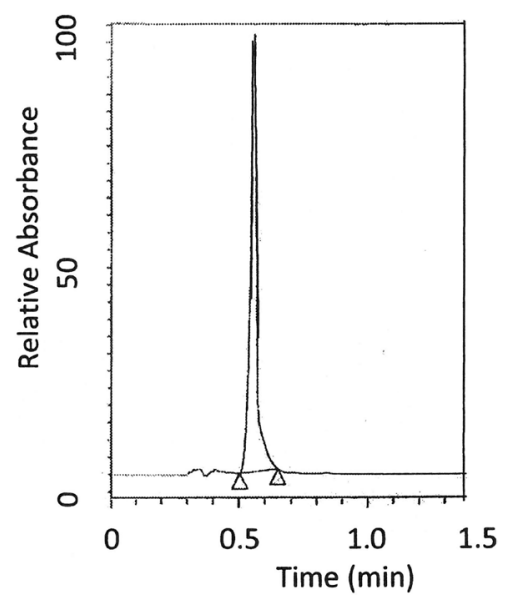

B

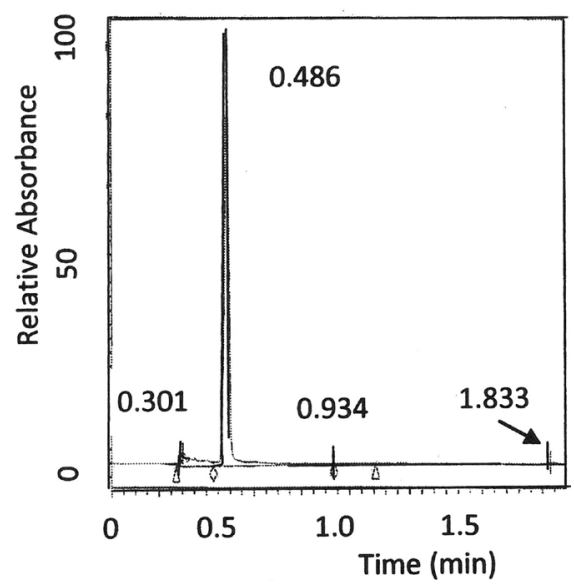

Figure 6. UPLC chromatogram of triphenyltin chloride in solution at zero time (A) and after 6 months at room temperature (B). A: Peak RT (retention time) $0.557 \mathrm{~min}$, area $866513 \mathrm{RA}$. B: Peak RT $0.301 \mathrm{~min}$, area $90185 \mathrm{RA}$; RT $0.486 \mathrm{~min}$, area $854035 \mathrm{RA}$; RT $0.934 \mathrm{~min}$, area $5247 \mathrm{RA}$; RT $1.833 \mathrm{~min}$, area $13030 \mathrm{RA}$. (Area of peaks shown as "relative absorbance units", RA).

\section{References}

Arp HP, Eek E, Nybakk AW, Glette T, Moskeland T, Pettersen A (2014): When will the TBT go away? Integrating monitoring and modeling to address TBT's delayed disappearance in the Drammensfjord, Norway. Water Res. 65, 213-223 https://doi.org/10.1016/j.watres.2014.06.041

Brtko J, Dvorak Z (2011): Role of retinoids, rexinoids and thyroid hormone in the expression of cytochrome P450 enzymes. Curr. Drug Metab. 12, 71-88 https://doi.org/10.2174/138920011795016881

Brtko J, Dvorak Z (2015): Triorganotin compounds - ligands for „rexinoid“ inducible transcription factors: Biological effects. Toxicol. Lett. 234, 50-58 https://doi.org/10.1016/j.toxlet.2015.02.009 
Carstensen JT (1995): Drug Stability - Principles and Practices. 2nd Ed., Marcel Dekker, Inc., New York-Basel-Hong Kong

Cole RF, Mills GA, Parker R, Bolam T, Birchenough A, Kröger S, Fones GR (2015): Trends in the analysis and monitoring of organotins in the aquatic environment. Trends Environ. Anal. Chem. 8, 1-11 https://doi.org/10.1016/j.teac.2015.05.001

Flodrova D, Toporova L, Macejova D, Lastovickova M, Brtko J, Bobalova J (2016): A comparative study of protein patterns of human estrogen receptor positive (MCF-7) and negative (MDA-MB-231) breast cancer cell lines. Gen. Physiol. Biophys. 35, 387-392 https://doi.org/10.4149/gpb_2016009

Kannan K, Takahashi S, Fujiwara N, Mizukawa H, Tanabe S (2010): Organotin compounds, including butyltins and octyltins, in house dust from Albany, New York, USA. Arch. Environ. Contam. Toxicol. 58, 901-907 https://doi.org/10.1007/s00244-010-9513-6

Kotake Y (2012): Advances in biology and toxicology of environmental metals/metalloids: Molecular mechanisms of environmental organotin toxicity in mammals. Biol. Pharm. Bull. 35, 1876-1880 https://doi.org/10.1248/bpb.b212017

leMaire A, Grimaldi M, Roecklin D, Dagnino S, Vivat-Hannah V, Balaguer P, Bourguet W (2009): Activation of RXR-PPAR heterodimers by organotin environmental endocrine disruptors. EMBO Rep. 10, 367-373 https://doi.org/10.1038/embor.2009.8

Macejova D, Toporova L, Brtko J (2016): The role of retinoic acid receptors and their cognate ligands in reproduction in a context of triorganotin based endocrine disrupting chemicals. Endocr. Regul. 50, 154-164 https://doi.org/10.1515/enr-2016-0018

Macejova D, Toporova L, Brtko J (2017): Effects of natural ligands and synthetic triorganotin compounds of nuclear retinoid $\mathrm{X}$ receptors in human MCF-7 breast cancer cell line. Gen. Physiol. Biophys. 36, 481-484 https://doi.org/10.4149/gpb_2017038

Nakanishi T, Nishikawa J, Hiromori Y, Yokoyama H, Koyanagi M, Takasuga S, Ishizaki J, Watanabe M, Isa S, Utoguchi N, et al. (2005): Trialkyltin compounds bind retinoid X receptor to alter human placental endocrine functions. Mol. Endocrinol. 19, 2502-2516 https://doi.org/10.1210/me.2004-0397

Nakanishi T (2008): Endocrine disruption induced by organotin compounds; organotins function as a powerful agonist for nuclear receptors rather than aromatase inhibitor. J. Toxicol. Sci. 33, 269-276 https://doi.org/10.2131/jts.33.269

Rodriguez-Cea A, Rodriguez-Gonzalez P, Font Cardona N, Aranda Mares L, BallesterNebot S, Garcia Alonso JI (2015): Determination of ultratrace levels of tributyltin in waters by isotope dilution and gas chromatography coupled totandem mass spectrometry. J. Chromatogr. A 1425, 265-272 https://doi.org/10.1016/j.chroma.2015.11.031

Sousa ACA, Pastorinho MR, Takahashi S, Tanabe S (2014): History of organotin compounds, from snails to human. Environ. Chem. Lett. 12, 117-137 https://doi.org/10.1007/s10311-013-0449-8

Suzdalev S, Gulbinskas S, Blazauskas N (2015): Distribution of tributyltin in surface sediments from transitional marinelagoon system of the south-eastern Baltic Sea, Lithuania. Environ. Sci. Pollut. Res. Int. 22, 2634-2642 https://doi.org/10.1007/s11356-014-3521-4

Toporova L, Macejova D, Brtko J (2016): Radioligand binding assay for accurate determination of nuclear retinoid $\mathrm{X}$ receptors: A case of triorganotin endocrine disrupting ligands. Toxicol. Lett. 254, 32-36 https://doi.org/10.1016/j.toxlet.2016.05.005

Received: September 17, 2017

Final version accepted: October 18, 2017 